\title{
Electrochemical Reduction Potentials of 1-Nitropyrene, 9-Nitroanthracene, 6-Nitrochrysene and 3-Nitrofluoranthene and their Correlation with Direct-Acting Mutagenicities
}

\author{
Wilson Araújo Lopes ${ }^{*, a}$, Pedro Afonso de Paula Pereira ${ }^{a}$, Hans Viertler ${ }^{b}$ \\ and Jailson B. de Andrade ${ }^{a}$
}

\author{
anstituto de Química, Universidade Federal da Bahia, Campus de Ondina, 40170-290 Salvador - BA, Brazil \\ ${ }^{b}$ Instituto de Química, Universidade de São Paulo, Cidade Universitária, 05599-970 São Paulo - SP, Brazil
}

\begin{abstract}
Neste trabalho, são apresentados os potenciais de meia-onda de redução, determinados para 3nitrofluoranteno $(3-\mathrm{NF})=-0,51 \mathrm{~V}, 1$-nitropireno $(1-\mathrm{NP})=-0,61 \mathrm{~V}, 6$-nitrocriseno $(6-\mathrm{NC})=-0,64 \mathrm{~V}$, e 9-nitroantraceno $(9-\mathrm{NA})=-0,84 \mathrm{~V}$. Os experimentos de voltametria cíclica com os nitro-PAH foram conduzidos em $\mathrm{N}, \mathrm{N}$-dimetilformamida anidra (DMF) contendo perclorato de tetraetilamônio $0,1 \mathrm{~mol} \mathrm{~L}^{-1}$ (TEAP), usando-se uma célula de três compartimentos, equipada com eletrodos de trabalho e auxiliar de platina e eletrodo de referência de Ag/AgI (fio de prata imerso em DMF/ TEAP $0,1 \mathrm{~mol} \mathrm{~L}^{-1}$, contendo iodeto de tetrabutilamônio $0,05 \mathrm{~mol} \mathrm{~L}^{-1}$ ). Esses potenciais podem ser ordenados do menos negativo para o mais negativo, o que corresponde à mesma ordem com que decresce a ação mutagênica direta (3-NF $>>1-\mathrm{NP}>6-\mathrm{NC}>>$ 9-NA). Assim, o 3-NF, que apresentou o potencial de meia-onda menos negativo é, entre os nitro-PAH estudados, o de maior atividade mutagênica. Deste modo, estas propriedades podem ser utilizadas como indicativas do risco à saúde humana da exposição a nitro-PAH, sendo, portanto, de grande importância em estudos toxicológicos.
\end{abstract}

In this work, we report measured electrochemical half-wave reduction potentials of 3nitrofluoranthene (3-NF), 1-nitropyrene (1-NP), 6-nitrochrysene (6-NC) and 9-nitroanthracene (9$\mathrm{NA}):=-0.51 \mathrm{~V} ;-0.61 \mathrm{~V} ;-0.64 \mathrm{~V}$; and $-0.84 \mathrm{~V}$ respectively. The cyclic voltammetry experiments with the nitro-PAH were carried out in anhydrous $\mathrm{N}, \mathrm{N}$-dimethylformamide (DMF), containing $0.1 \mathrm{~mol}$ $\mathrm{L}^{-1}$ tetraethylammonium perchlorate (TEAP) using a three-compartment cell fitted with Pt working and auxiliary electrodes, and a $\mathrm{Ag} / \mathrm{AgI}$ reference electrode (a silver wire in $0.1 \mathrm{~mol} \mathrm{~L}^{-1} \mathrm{DMF} / \mathrm{TEAP}$ containing $0.05 \mathrm{~mol} \mathrm{~L}^{-1}$ tetrabutylammonium iodide). These potentials can be ordered from the less to the more negative value, which corresponds to the same order by which the direct-acting mutagenicity decreases (3-NF $>>1-\mathrm{NP}>6-\mathrm{NC}>>$ 9-NA). Thus, 3-NF, which shows the less negative first halfwave potential value is the more active mutagenic amongst the nitro-PAH studied. In this way, these properties may be used as an indicative of the health risks, asociated to nitro-PAH exposure, and thus being of great importance in toxicological studies.

Keywords: nitro-PAH, voltammetric peak potentials, mutagenic activity

\section{Introduction}

Nitro-polycyclic aromatic hydrocarbons (nitro-PAH), are semivolatile organic compounds which are primarily emitted as combustion products and have been identified as a class of genotoxic environmental pollutants. ${ }^{1-5}$ These compounds require metabolism to exert their biological activities and both ring oxidation and reduction of the nitro substituent may be involved in their metabolic activation. ${ }^{6,7}$ As the halfwave reduction potential is a measure of the energy required for reduction of the nitro group, less negative values suggest more ease of reduction than others with more negative values. ${ }^{8}$

* e-mail: willopes@ufba.br
Mutagenic activity is determined by a test developed by Ames et al., ${ }^{9}$ in experiments making use of the bacteria Salmonella. A compound is considered a mutagen (positive) if it produces a reproducible, doserelated increase in the number of revertant colonies in one or more strains. A compound is considered a nonmutagen (negative) if no dose-related increase in the number of revertant colonies is observed in at least two independent experiments. Mutagenic activity is generally reported as reversions per $\mathrm{m}^{3}$ of air (volume) or reversions per $\mu \mathrm{g}$ (mass).

The orientation of the nitro group has been found to be an important structural feature that affects oxidation and reduction mechanisms. ${ }^{4}$ Depending upon the geometric 
location of the nitro substituent, there are in general two types of nitro-PAH. Type I has the nitro group perpendicular or nearly perpendicular to the aromatic ring (e.g. 1-nitrobenzo[e]pyrene), while the Type II has the nitro group parallel or nearly parallel to the aromatic ring (e.g. 3-nitrobenzo[e]pyrene). ${ }^{8}$ In the same way, biological activity of nitro-PAH depends on its molecular structure.

Studies have been conducted in order to correlate the nitro-PAH structure and the half-wave reduction potential with mutagenic activity. ${ }^{10,11}$ Shaikh et al. ${ }^{8}$ determined the half-wave reduction potentials of nitrobenzo[a]pyrene, nitrobenzo[e]pyrene and nitrobenz[a]anthracene and established a qualitative relationship where both first half-wave potential and the orientation of the nitro group are important electronic and structural features for correlation with the direct-acting mutagenicity of nitro-PAH. However, possible exception to the hypothesis that perpendicular orientation exhibits weak or no direct-acting mutagenicity has been observed, ${ }^{8}$ requiring new studies involving other nitro-PAH.

In this work, the electrochemical half-wave reduction potentials of 1-nitropyrene, 9-nitroanthracene, 6-nitrochrysene and 3-nitrofluoranthene were measured, as well as the UV spectra of chrysene and benzo[a]anthracene were compared, respectively, to the their nitro derivatives 6nitrochrysene and 7-nitrobenzo[a]anthracene. These results were used to correlate the nitro group orientation and directacting mutagenicity (determined elsewhere). ${ }^{6}$

\section{Experimental}

\section{Chemicals}

1-nitropyrene (1-NP) and 9-nitroanthracene (9-NA) were synthesized by direct nitration of the respective PAH with $\mathrm{HNO}_{3}(90 \%)$, in dioxane at $25{ }^{\circ} \mathrm{C} \cdot \cdot^{12,13}$ The purity of compounds (higher than 95\%) were determined by gas chromatography coupled to mass spectrometry (GC-MS). The 6-Nitrochrysene (6-NC) and 3-Nitrofluoranthene (3$\mathrm{NF}$ ) were purchased from AccuStandard INC ${ }^{\mathrm{TM}}$ (USA) and used as received.

\section{Electrochemical studies}

The cyclic voltammetry experiments with the nitroPAH were carried out in anhydrous $\mathrm{N}, \mathrm{N}$-dimethylformamide (DMF), containing $0.1 \mathrm{~mol} \mathrm{~L}^{-1}$ tetraethylammonium perchlorate (TEAP) using a three-compartment cell fitted with a Pt bead working electrode, a Pt plate auxiliary electrode, and a Ag/AgI reference electrode (a silver wire in $0.1 \mathrm{~mol} \mathrm{~L}^{-1}$ DMF/TEAP containing $0.05 \mathrm{~mol}$ $\mathrm{L}^{-1}$ tetrabutylammonium iodide). The voltammograms were acquired with a PAR 273A potentiostat (Princeton Applied Research Corporation, Princeton, NJ, USA) and registered on a PAR Model RE0074 x-y recorder.

$10 \mathrm{~mL}$ of the TEAP/DMF solution were transferred to the working compartment of the cell and purged with dry nitrogen for about $30 \mathrm{~min}$. After recording a background voltammogram between +0.4 and $-1.8 \mathrm{~V} v s \mathrm{Ag} / \mathrm{AgI}$, at $100 \mathrm{mV} \mathrm{s}^{-1}, 5 \mathrm{mg}$ of each nitro-PAH were added to the solution and, after nitrogen purge, cyclic voltammograms were recorded at 50, 100 and $200 \mathrm{mV} \mathrm{s}^{-1}$. Figure 1 shows the voltammogram of 3-Nitrofluoranthene and Table 1 lists the peak values of the first cathodic potentials $\left(\mathrm{Ep}_{\mathrm{c}}\right)$ of each nitro-PAH determined in this work.

\section{UV spectra}

Spectra were recorded on a spectrophotometer (Cary, model 500 UV/Vis., Varian Corp.) at room temperature using fresh solutions in spectroscopic grade methanol. Spectra were measured in $1 \mathrm{~cm}$ quartz-stoppered cuvettes against pure methanol as reference.

\section{Results and Discussion}

It is known that the biological activity of a nitro-PAH is dependent on its molecular structure. For example, 2-nitronaphthalene induces cancer in animals, while 1-nitronaphthalene does not. ${ }^{14,15}$ Thus, it would be useful to develop protocols by which could one distinguish biological activities among the isomers of nitro-PAH. The peak of the first reduction potential, of the nitro-groups, would be useful to assess the potential risk to the environment and the human health, of the nitro-PAH isomers.

The four nitro-PAH studied in this work, when ordered by their decreasing values of first cathodic potential, which corresponds to a reversible electron transfer involving the nitro group, stay as follow, according to Table 1: 3-NF $>1-\mathrm{NP}>6-\mathrm{NC}>9-\mathrm{NA}$. This is the same way by which they may be organized regarding their direct-acting mutagenicity: $3-\mathrm{NF}>>1-\mathrm{NP}>6-\mathrm{NC}>>9$ NA. They also show a reasonable correlation with the nitro group orientation (Table 1). The 9-nitroanthracene has its nitro substituent in a L-region, which means that it suffers a significant steric hindrance from the two hydrogen atoms in the 1 and 8 positions. As consequence, the nitro group is best oriented perpendicularly to the plane of the aromatic ring, since in this way that hindrance will be reduced. This orientation, on the other way, does not turn possible a delocalization of the $\pi$-electrons of 
Table 1. First cathodic peak potentials (Epc) and mutants per nmol of nitro-PAH

6-Nitrochrysene

* Values obtained from reference 6 .

the nitro group via conjugation with the aromatic ring, and this would be partially explaining the smallest potential found for this compound. The 9-nitroanthracene, which may be classified as Type I nitro-PAH, which means it has the nitro group perpendicular or nearly perpendicular to the aromatic ring, showed the most negative peak potential and presents a very low directacting mutagenicity.

The three other nitro-PAH (3-NF, 1-NP, 6-NC), Table 1 , on the other hand, have just one hydrogen atom which can offer a direct hindrance to the nitro group, and so the sterical effects are considerable lower than in the previous case. The nitro group tends to assume a parallel or nearly parallel position relative to the aromatic ring, and therefore presents a less negative potential, due to the conjugation of its $\pi$-electrons with the aromatic ring. They are classified as Type II nitro-PAH and showed considerable higher direct-acting mutagenicity, compared to 9-nitroanthracene. Obviously, there are other properties that may influence the potentials and mutagenicity, as the structural arrangement of the aromatic rings in the molecule, for example.

The effects of steric hindrance on the orientation of the $\mathrm{NO}_{2}$ group, and its conjugation with the double bonds in the aromatic ring, can also be studied by the UV spectra of compounds. In Figure 2, the UV spectra of chrysene and benzo[a]anthracene were compared, respectively, to their nitro derivatives 6-nitrochrysene and 7-nitrobenzo[a]anthracene. For the first pair, the steric hindrance on the nitro group, due to the hydrogen atoms, is only partial, and thus a conjugation effect is possible, with changes in the transition energies. This is shown by different patterns presented by both spectra.
For benzo[a]anthracene and 7-nitrobenzo[a]anthracene, on the other way, the steric hindrance on the $\mathrm{NO}_{2}$ group is considerable. Thus, the conjugation effect is absent and the UV spectra for both compounds are very similar, according to Figure 2. Thus, when comparing 6-nitrochrysene and 7nitrobenzo[a]anthracene isomers, the latter may be classified as Type I nitro-PAH, while the former can be classified as Type II nitro-PAH. ${ }^{6}$ The direct-acting mutagenicity seems to be, again, well correlated with the nitro group orientation relative to the aromatic ring, since for 6-nitrochrysene the reported value is almost 1000 times higher than for its isomer

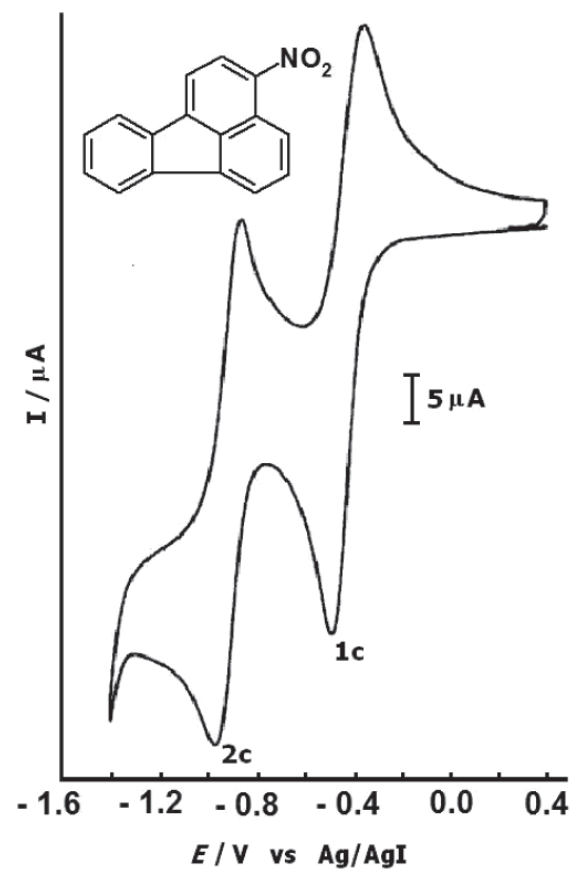

Figure 1. Cyclic Voltammogram of 3-NF in DMF /TEAP $0.1 \mathrm{~mol}$ $\mathrm{L}^{-1}$; scan rate $=50 \mathrm{mV} \mathrm{s}^{-1}$. 

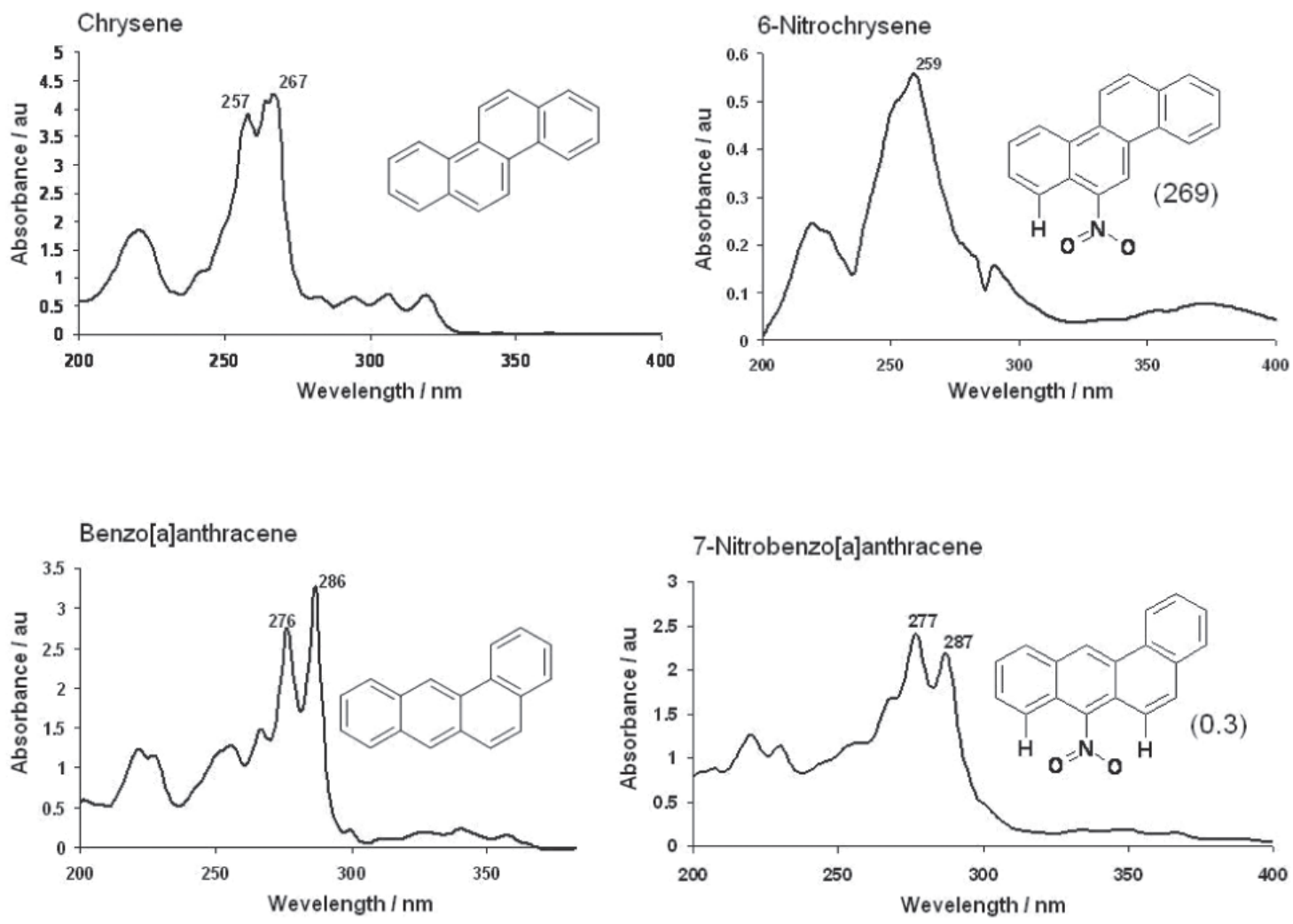

Figure 2. UV spectra of Chrysene, Benzo[a]anthracene, 6-Nitrochrysene and 7-Nitro-benzo[a]anthracene, and mutants per nmol (in parenthesis), from ref. 6, of 6-Nitrochrysene and 7-Nitro-benzo[a]anthracene.

(Figure 2). Unfortunately, we couldn't make a similar comparison using our measured first cathodic potential for 6-nitrochrysene $(-0.64 \mathrm{~V})$, and the measured by Skaikh et al. ${ }^{8}$ for the 7 -nitrobenzo[a] anthracene isomer $(-0.98 \mathrm{~V})$ since different electrochemical techniques were used, namely cyclic voltammetry (this work) and polarography. ${ }^{8}$

Finally, this work supports previous studies which state that both the first reduction potential and the orientation of the nitro substituent are important electronic and structural features for correlation with the direct-acting mutagenic of nitro-PAH. Thus, these properties may be used as an indicative of the human health risk of exposure to the nitro-PAH, which is of paramount importance in environmental and toxicological studies.

\section{Conclusions}

The first cathodic peak potentials, measured in this study for 9-nitroanthracene, 6-nitrochrysene, 1nitropyrene and 3-nitrofluranthene, may be ordered in the same way as the direct-acting mutagenicity: 3-NF $>>1-\mathrm{NP}>6-\mathrm{NC}>>$ 9-NA. These potential values, associated to nitro group orientation, seem to be useful in the assessment of the trend of the direct-acting mutagenicity of the nitro-PAH and thus the human health risk due to exposure to them. These results are useful in toxicological assessments of air toxics.

\section{Acknowledgments}

We are grateful to FAPESB, FINEP and CNPq for financial support and for fellowships, to N.C. Bahia for helping in experiments and especially to Dr. A. H. Miguel (UCLA) for helpful suggestions and discussions.

\section{References}

1. Chan, T. L.; Gibson, T. L. In Nitrated Polycyclic Aromatic Hydrocarbons; White, C.M., ed.; Huething: New York, 1985, p. 237.

2. Moreira, J. C.; Quim. Nova 1995, 18, 362.

3. Lopes, W.A.; de Andrade, J.B.; Quim. Nova 1996, 19, 497.

4. Wu, Y.S.; Wang, Y.K.; Lai, C.C.; Lai, J.S.; Umruh, L.E.; Evans, F.E.; Fu, P.P. In Polynuclear Aromatic Hydrocarbons: Measurements, Means, and Metabolism; Cooke, M.; Loening, K.; Merritt, J., eds.; Battelle Press: Columbus, 1991, p. 1.083.

5. Pereira Netto, A.D.; Moreira, J.C.; Dias, A.E.X.O.; Arbilla, G.; Ferreira, L.F.V.; Oliveira, A.S.; Barek, J.; Quim. Nova 2000, 23,765 . 
6. Rosenkranz, H.; Mermelstein, R. In Nitrated Polycyclic Aromatic Hydrocarbons; White, C.M., ed.; Huething: New York, 1985, ch. 6.

7. Jacob, J.; Karcher, W.; Belliardo, J.J.; Wagstaffe, P.J.; Fresenius' Z. Anal. Chem. 1986, 1.

8. Shaikh, A.U.; Jia, C.; Yang, D.T.C.; Watson, H.; Fu, P.P. In Polynuclear Aromatic Hydrocarbons: Measurements, Means, and Metabolism; Cooke, M.; Loening, K.; Merritt, J., eds.; Battelle Press: Columbus, 1991, p. 819.

9. Ames, B. N.; McCann, J.; Yamasaki, E.; Mutation Res. 1975, 31, 347.

10. Fu, P.P.; Von Tungeln, L.S.; Chou, M.W.; Carcinogenesis 1985 , 6, 753; Fu, P.P.; Heflich, R.H.; Von Tungeln, L.S.; Yang, D.T.C.; Fifer, E.K.; Beland, F.A.; Carcinogenesis 1986, 7, 1819; Fu, P.P.; Chou, M.W.; Miller, D.W.; White, G.L.; Heflich, R.H.; Beland, F.A.; Mutation Res. 1985, 143, 173; Vance, W.A., Levin, D.W.; Environ. Mutagenesis 1984, 6, 797.

11. Abreu, F.C.; Ferraz, P.A.L.; Goulart, M.O.F.; J. Braz. Chem. Soc. 2002, 13, 19.
12. Ruehle, P.H.; Bosch, L.C.; Duncan, W.P. In Nitrated Polycyclic Aromatic Hydrocarbons; White, C.M., ed.; Huething: New York, 1985, ch. 4.

13. Zielinska, B.; Arey, J.; Harger, W.P. In Polynuclear Aromatic Hydrocarbons: Measurements, Means, and Metabolism; Cooke, M.; Loening, K.; Merritt, J., eds.; Battelle Press: Columbus, 1991, p. 1107.

14. White, C. M. In Nitrated Polycyclic Aromatic Hydrocarbons; White, C. M., ed.; Huething: New York, 1985, p. 1.

15. Poirier, L.A.; Weisburger, E.K.; J. Nat. Cancer Inst. 1979, 62, 833; Griesemer, R.A.; Cueto Jr. In Molecular Cellular Aspects of Carcinogen Screening Tests; Montesano, R.; Bartsch, H.; Tomatis, L., eds.; IARC Scientific Publication $\mathrm{N}^{\circ} 27$, International Agency for Research on Cancer, 1980, p.259.

Received: August 9, 2005

Published on the web: October 26, 2005

FAPESP helped in meeting the publication costs of this article. 